University of Montana

ScholarWorks at University of Montana

6-1998

\title{
Insect Herbivory Above- and Belowground: Individual and Joint Effects on Plant Fitness
}

John L. Maron

University of Montana - Missoula, john.maron@mso.umt.edu

Follow this and additional works at: https://scholarworks.umt.edu/biosci_pubs

Part of the Biology Commons

Let us know how access to this document benefits you.

\section{Recommended Citation}

Maron, John L., "Insect Herbivory Above- and Belowground: Individual and Joint Effects on Plant Fitness" (1998). Biological Sciences Faculty Publications. 340.

https://scholarworks.umt.edu/biosci_pubs/340

This Article is brought to you for free and open access by the Biological Sciences at ScholarWorks at University of Montana. It has been accepted for inclusion in Biological Sciences Faculty Publications by an authorized administrator of ScholarWorks at University of Montana. For more information, please contact scholarworks@mso.umt.edu. 


\title{
INSECT HERBIVORY ABOVE- AND BELOWGROUND: INDIVIDUAL AND JOINT EFFECTS ON PLANT FITNESS
}

\author{
JOHN L. MARON ${ }^{1}$ \\ University of California Bodega Marine Laboratory, Box 247, Bodega Bay, California 94923 USA
}

\begin{abstract}
Understanding of the selective effects of insect herbivory on plants comes primarily from studies of herbivory aboveground. The impact of belowground herbivory, either in isolation or in concert with herbivory aboveground, on plant fitness is only beginning to be understood.

I reduced the densities of root-boring ghost moth (Hepialus californicus) larvae and/or flower- and seed-feeding insects of bush lupine (Lupinus arboreus), a woody shrub, and followed fecundity and survival of plants for three years. In year one, suppression of aboveground herbivores increased mean seed output by $31 \%$, but suppression of belowground herbivores had no significant effect on plant fecundity. In year two, suppression of aboveground herbivores increased mean seed production by $123 \%$, and belowground herbivores again had no significant effect on plant fecundity. In year three, suppression of aboveground herbivores had little effect on lupine fecundity; plants protected from root borers, however, produced, on average, $85 \%$ more pods and $83 \%$ more seeds compared with unprotected plants. In each of the three years, there was no statistical interaction between herbivory above- and belowground; effects of individual herbivores on plant fitness were additive.

Both modes of herbivory had significant cumulative effects on lupine fitness. Protection from chronic aboveground herbivory increased mean cumulative seed output over 3 yr by $78 \%$; suppression of belowground herbivores increased mean cumulative seed production by $31 \%$. Cumulative average mortality across all three years was $18 \%$ greater for plants exposed to root herbivory than for plants protected from root herbivory. Taken together, results show that both above- and belowground herbivores can potentially impose strong selection on bush lupine.
\end{abstract}

Key words: bush lupine; herbivory, above-and belowground; insect herbivory; plant fitness.

\section{INTRODUCTION}

Impressions of how phytophagous insects affect plant performance come primarily from studies of herbivory aboveground (see reviews by Belsky 1986, Crawley 1989, Gange 1990, Marquis 1992). Belowground insect herbivory has received relatively little attention in the ecological literature (Brown and Gange 1990), despite the fact that subterranean herbivores are common (Scott et al. 1979, Brown and Gange 1990) and often quite damaging (Parker 1985, Ingham and Detling 1986, Andersen 1987, Prins et al. 1992, Strong et al. 1995). The agricultural literature contains many examples of root-feeding nematodes, aphids, moths, and beetles severely affecting plant fitness (Dutcher and All 1979, Clements and Bentley 1983, Dowler and Van Gundy 1984, Godfrey et al. 1986, Hagner and Jonsson 1995). Evidence for the ecological importance of belowground herbivores in natural systems comes primarily from pioneering community-level studies. Careful manipulative experiments have shown that

Manuscript received 23 December 1996; revised 12 May 1997; accepted 27 May 1997.

${ }^{1}$ Present address: Botany Department, University of Washington, Box 355325, Seattle, Washington 98195 USA. chronic root herbivory can alter plant community composition and change the course of secondary succession (Brown and Gange 1989a, 1992, Brown 1990) However, multiyear demographic studies examining how belowground insect herbivory alters plant fitness are rare. How community-level effects are manifested at the level of the individual plant remain a mystery (but see Muller-Scharer 1991, Muller-Scharer and Brown 1995).

In contrast to belowground herbivory, an enormous literature documents manifold effects of aboveground insect herbivores on individual plant performance (see reviews by Crawley 1989, Gange 1990, Marquis 1992). Although the majority of these studies focus on folivory, compelling experimental evidence also exists for floral and seed predators severely depressing plant fecundity (Waloff and Richards 1977, Louda 1982a, $b$, 1983, Auld 1986, Auld and Myerscough 1986, Zammit and Hood 1986, Andersen 1988, 1989, Louda and Potvin 1995, Wise and Sacchi 1996). Where annual plants are involved, these reductions in fecundity translate to losses in lifetime fitness, and selective effects are most easily inferred. Determining how herbivory affects perennial plant fitness is more difficult, because longer lived plants often compensate across years for herbi- 
vore damage (Hendrix 1988, Mattson et al. 1996). Further, multiple functional groups of aboveground herbivores can interact (Williams and Myers 1984, Faeth 1986, Martin et al. 1994, Pilson 1996), and these interactions can produce complex, subtle, and cumulative impacts on plant demography that can be overlooked in short-term studies (Fox 1981, Strauss 1991, Doak 1992, Root 1996).

Plants are frequently damaged simultaneously by insects that feed above- and belowground (Brown and Gange 1989b, Muller-Scharer and Brown 1995). How might above- and belowground herbivores differ in the intensity of selection they impose on plants? Some evidence suggests that plant growth response to abovevs. belowground herbivory may be quite different (Detling et al. 1980, Prins et al. 1992, Houle and Simard 1996). Herbivore feeding on aboveground plant tissue can affect the quality of belowground tissue (or vice versa), enabling the abundance of insects in one feeding guild to alter the performance of individuals in a second feeding guild (Seastedt et al. 1988, Gange and Brown 1989, Moran and Whitham 1990, Masters et al. 1993, Masters 1995). The extent to which interactions of this sort result in above- and belowground damage that is additive or interactive for plant fitness is poorly known (but see Reichman and Smith 1991).

At my study site in coastal California, both aboveand belowground insect herbivores attack a productive, competitively dominant shrub, bush lupine (Lupinus arboreus). Individual lupines, and occasionally even entire stands, die at a young age, and frequent death coupled with episodic recruitment out of the seed bank results in large fluctuations in lupine cover at some sites (Davidson 1975, Strong et al. 1995). Because lupines are potent nitrogen fixers, which can rapidly enrich nitrogen-poor sandy soils (Gadgil 1971, Bentley and Johnson 1994, Maron 1996), the rapid turnover of lupine populations can have large impacts on plant community composition (Maron and Connors 1996) and ecosystem-level processes (Maron 1996). Previous correlative research suggested that bouts of plant dieoff were due to heavy belowground insect herbivory (Strong et al. 1995). However, the effect of belowground insect herbivory on lupine fitness has not been experimentally assessed, nor has it been ascertained whether damage to bush lupine resulting from aboveand belowground herbivory is additive or interactive.

The goal of this study was to experimentally assess the individual, interactive, and cumulative effects of belowground root herbivory and aboveground floral and seed herbivory on bush lupine growth, fecundity, and survival. By suppressing the densities of belowand aboveground herbivores in a factorial experiment, I determined how these differing modes of herbivory affect the fecundity and survival of lupine in an evenaged stand.

\section{Methods}

Study site and natural history of

bush lupine and its herbivores

This study took place on the University of California's Bodega Marine Reserve (BMR), a 147-ha biological reserve located on the Pacific coast in Sonoma County, California (see Barbour et al. 1973 for a description of the study site). Bush lupine is a short-lived, woody, evergreen shrub that is abundant on BMR, where it forms dense stands within coastal prairie grasslands and is scattered throughout the dunes that lie within the San Andreas fault zone. Bush lupines do not have a highly branched root system with many fine roots. Rather, plants form a long central tap root, and occasionally also produce a few large side roots. In grasslands, lupine seedling recruitment is episodic, and seedling abundance can vary by several orders of magnitude between years (Maron and Simms 1997). Because recruitment is pulsed, many lupine stands are even-aged (Davidson 1975).

Lupine seedlings emerge with the onset of winter rains. Plants grow quickly, and the majority of mature lupines begin to flower in their second spring (only rarely do lupines flower in their first summer). By midsummer, flowers develop into large $(\sim 3-6 \mathrm{~cm}$ long) legumes, from which seeds dehisce explosively in late summer. Bush lupine seeds have a testa-enforced dormancy, and in grasslands many seeds remain dormant but viable in a long-lived seed bank (Maron and Simms 1997).

Bush lupines along the California coast are attacked by a diverse insect fauna, with large spatial variation in the abundance of specific herbivores (Davidson 1975, Harrison and Karban 1986, Harrison 1994, Strong et al. 1995). Western tussock moth larvae (Orgyia vetusta) can occur at high densities and completely defoliate lupine, but these herbivores are usually spatially restricted to a rather small portion of BMR (Harrison and Maron 1995). Other defoliators can be very abundant across larger areas, but only occur occasionally (Davidson 1975; E. D. Davidson, personal communication). In this study, there were no folivorous caterpillars on experimental plants; however, several insects fed within lupine flowers and seed pods, damaging flower ovaries and developing seeds in pods. Ovary damage was most often correlated with the presence of small dipteran, geometrid (Lepidoptera, Geometridae), and weevil (Apion procliva; Coleoptera, Apionidae) larvae. Dipteran larvae emerge in spring, pupate in early summer, and eclose in spring of the next year. Adult flies and their eggs are commonly seen inside flowers in early spring. Geometrid larvae pupate in late spring before metamorphosis in late summer. The geometrid could only be identified to genus ( $E u$ pithecia spp; Geometridae, Larentiinae). The identity of the dipteran remains unknown. The principal consumers of developing seeds in lupine pods were weevil 
(Apion procliva) and dipteran (Delia lupini, Anthomyiidae, Diptera) larvae. Since there were few folivores attacking plants, to simplify the remainder of this paper, I refer collectively to the group of insects that damage flower ovaries and developing seeds as "aboveground herbivores."

The main belowground insect herbivore on bush lupine was larvae of the ghost moth (Hepialus californicus). These larvae feed within the central shoot and tap root of lupines (i.e., that portion of the shoot and root that occurs within $15 \mathrm{~cm}$ above or below the soil surface) and, at BMR, most lupines harbor ghost moth larvae (Opler 1968, Davidson 1975, Strong et al. 1995). Although other small larvae can occasionally also be found on the outside or inside of lupine roots, these other insect herbivores are rare, very small, and impose little damage relative to $H$. californicus (J. L. Maron, personal observation).

Ghost moths are univoltine; pupae eclose in late fall, and females broadcast many hundreds to several thousand eggs while flying over patches of lupine bushes during winter and spring nights (Wagner 1986; A. Whipple, personal communication). Small first and second instar larvae develop in the soil under lupines and feed on the exterior of the upper portions of lupine tap root. By mid- to late spring, caterpillars burrow into plants and create extensive feeding galleries inside a plant's central shoot and at the top portion of the plant's central tap root. Larger caterpillars seldom move between lupines. Often, many caterpillars can be found inside the same plant and damage to plant tissue can be extensive (Strong et al. 1995). Individuals complete their development in fall, when they pupate.

\section{Insect manipulation experiments}

To examine the interactive and cumulative effects of above- and belowground herbivory on lupine demography, I conducted a fully factorial randomized block design experiment in which I manipulated the density of herbivores within plots established in a stand of 1yr-old lupines. This stand was located within a $31.5 \times$ $31.5 \mathrm{~m}$ fenced plot that had been previously cleared of vegetation and covered with black plastic in spring 1992. After the plastic was removed in fall 1992, a large number of bush lupine seedlings emerged with the onset of winter rains. On 31 August 1992, I counted and marked with wire flags a total of 559 seedlings within this plot. In December 1993, 398 of the 559 seedlings $(71 \%)$ remained alive.

In December 1993 I established seven experimental blocks within this lupine stand. Each experimental block consisted of four plots, each receiving a different randomly assigned treatment. Plots received the same treatment across all $3.5 \mathrm{yr}$ of the study. Plots varied in size (range $4.6-13.7 \mathrm{~m}^{2}$ ), and the number of plants in each plot varied between 6 and 12, although there was no significant difference between 28 plots in plant density (ANOVA, $F_{3,24}=0.4, P=0.75$ ). Plots were sep- arated from each other by at least $1 \mathrm{~m}$. All plants within the same plot received one of the following treatments: (1) reduction of flower- and seed-feeding insects, (2) reduction of root-feeding insects, (3) suppression of both above- and belowground herbivores, and (4) no herbivore suppression. Aboveground herbivores were reduced by spraying lupine foliage, flowers, and seed pods with the insecticide Sevin (Union Carbide Corporation, Danbury, Connecticut), at a concentration of $2.1 \mathrm{~mL}$ active ingredient/L of water (application rate $=\sim 70 \mathrm{~mL}$ of insecticide/water mixture per plot). Belowground ghost moth larvae were killed by spraying lupine trunks and the soil at the base of plants with the insecticide Dursban (DowElanco Corporation, Midland, Michigan), at a concentration of $0.5 \mathrm{~mL}$ active ingredient $/ \mathrm{L}$ water (application rate $=40 \mathrm{~mL}$ insecticide/water mixture per plot). Both above- and belowground herbivores were suppressed by applying both insecticides to the same plants (application rates as above). Control plants receiving ambient levels of herbivory were sprayed with water. This treatment served as a control for the small amounts of water applied with insecticides. All lupines in each plot were individually marked with wire flags attached to bamboo poles that were sunk in the ground.

Dursban has been extensively and successfully used in studies of belowground herbivory (Brown and Gange $1989 a, b)$. The active ingredient in Dursban is chlorpyrifos [0,0-diethyl-0-(3,5,6-trichloro-2-pyridinyl) phosphorothioate], an organophosphate that contains one atom of phosphorus. The active ingredient has no toxic effects on nitrogen-fixing Bradyrhyizobium bacteria, nitrifying and denitrifying bacteria, fungal populations (Pozo et al. 1995), earthworms (Clements et al. 1986), or spiders (Clements et al. 1988). Nor does it affect nodule number or size (Revellin et al. 1992).

The active ingredient in Sevin is Carbaryl (1-naphthyl $\mathrm{N}$-methylcarbamate; $\mathrm{C}_{12} \mathrm{H}_{11} \mathrm{NO}_{2}$ ). Carbaryl is a cholinesterase inhibitor that is effective against a wide range of insects. It is rapidly oxidized and decomposes relatively quickly; its half-life on various fruits ranges from 3 to 4 days (Kuhr and Dorough 1976). Although it can be phytotoxic to some plants, I have found no evidence for any phytotoxic effect on lupine. Neither Dursban nor Sevin are systemic, and application of Sevin to lupine foliage had no negative effects on ghost moth abundance in lupine roots and trunks (J. L. Maron, unpublished data).

I conducted separate experiments to ensure that neither insecticide had undue positive or negative effects on lupine growth. Application of Sevin every 2 wk for 3 mo (mid-February to May) to lupine seedlings that experienced no foliar herbivory had no effect on seedling growth (ANOVA, $F_{1,91}, P=0.63$ ). Monthly application of Dursban for 5 mo to lupine seedlings planted in pots and protected from ghost moth herbivory had no significant effect on aboveground dry plant biomass (ANOVA, $F_{1,28}=0.013, P=0.91$ ). 
In 1994, I sprayed all plants in each plot with water, Sevin, and/or Dursban every 10-14 d from January to May. In 1995 and 1996, I sprayed plants with Sevin only during the flowering season, from March to June. Separate experiments in 1995 revealed that ghost moth caterpillars could be excluded from lupine roots by applying small amounts of Dursban to exposed shoots at ground level on a monthly basis. These experiments also revealed that application of Dursban to lupine trunks and roots killed all ghost moth larvae, both on the exterior and interior of lupine roots and shoots ( $\mathrm{J}$ L. Maron, unpublished data). Therefore in 1995 and 1996, I only sprayed plants with Dursban every 3-4 wk from February to June, the period during which early instar ghost moth larvae are developing in the soil around lupine roots. Control plants were sprayed with water on the same schedule as above. Insecticides were always applied to plants early in the morning, before pollinators were active.

I censused all plants in each treatment plot every 3 mo, beginning in December 1993. I used dial calipers to measure the stem diameter at ground level of randomly selected lupines in each plot. Some plants had multiple trunks that were unconnected aboveground but connected underground; on these plants I measured each trunk at ground level. I used stem diameter measurements to calculate a total basal stem area for each plant. For plants with multiple stems, I calculated a basal area for each stem separately and then summed these values to obtain one estimate of total stem area per plant. I initially measured 6-12 randomly selected plants in each plot (the number of plants measured in each plot differed because plant abundance in each plot differed). Due to plant mortality, fewer plants per plot were measured in subsequent censuses. I used these measurements to calculate annual mean growth of individuals in each treatment plot for the periods December 1993-December 1994 and December 1994December 1995. I also calculated mean growth across a 2-yr and 2.5-yr period between December 1993 and December 1995, and between December 1993 and June 1996.

In June 1994 I counted the total number of seed pods on each of five randomly selected marked plants (out of a total of 6-12 plants/plot) in each plot within each block $(28$ plots $\times 5$ plants $=140$ plants total $)$. I repeated these counts in July 1995 and July 1996, but due to high plant mortality in the winter of 1995, fewer plants were available in each plot in these years. Therefore, I censused pods on $2-5$ plants/plot (mean $=3.2$ individuals/plot: 83 total plants) and 1-6 plants/plot (mean $=3.0$ individuals/plot: 77 total plants) in 1995 and 1996, respectively. High plant mortality during January and February 1995 coincided with extremely heavy rains. During this El Niño year, average annual rainfall totaled $165 \mathrm{~cm}$, a $114 \%$ increase in annual precipitation over the long-term 20-yr average on BMR (Bodega Marine Laboratory, unpublished data). Plants that eventually died exhibited classic signs of waterlogging: gray wilting leaves on drooped petioles. In total, 65 plants died, with no significant difference in the mean percentage mortality among treatment plots (ANOVA, $F_{3,24}=1.33, P=0.29$ ).

On the same individual bushes as above, I haphazardly chose and harvested 20 dried pods per plant and counted the total number of intact, filled seeds per pod. Pods were sampled just prior to dehiscence, when all seeds had fully developed. In 1995 and 1996 I repeated this procedure, and also recorded the number of seeds that were partially or completely eaten, and the number and identity of all insect larvae in each pod.

I used pod and seed data to calculate the mean seed pod production and the mean total seed output (total seed output $=$ number of pods $\times$ mean number of seeds per pod) of all sampled plants in each treatment plot in 1994-1996. Additional data taken in 1995 and 1996 enabled me to calculate for each bush the number of pods per raceme (pods per raceme $=$ total number of pods divided by total number of racemes), and the mean number of destroyed seeds per pod out of the 20 pods sampled on each bush.

\section{Insect abundance}

In spring 1995 and 1996 I initiated a parallel experiment to determine the density of flower-feeding insects on plants and the extent of damage caused to flowers. In both years I haphazardly selected 16 similarly sized large plants in an area immediately adjacent to my experimental plot, and randomly selected half of these individuals to receive a foliar insecticide treatment. Foliage on the remaining plants was sprayed with water, as a control. Starting when flower buds were first initiated (in early April 1995 and late April 1996), I sprayed plants with either Sevin or water every 10-12 d. Starting on 24 April 1995 and 6 May 1996, every 2 wk I removed two randomly selected racemes on each of the eight plants in the two treatment groups, placed each raceme in a labeled plastic bag, and immediately brought these in to the laboratory. I dissected each flower, counted the number of small fly and lepidopteran larvae in each flower, and recorded whether flowers had damaged ovaries.

Starting in the third week of May (1995 and 1996), every 8-14 d I also sampled aborted flowers from each of the 16 plants. Fresh, aborted flowers were collected in $15 \mathrm{~cm}$ diameter collars of remie fabric taped to the base of four racemes on each plant. To supplement these, I also collected freshly aborted flowers off the ground immediately under each plant (the same fraction of ground-collected flowers had damaged ovaries as did collar-collected flowers) (J. L. Maron, unpublished data). At each sampling period, 17-27 aborted flowers were collected for each plant. Aborted flowers were dissected in the same way as intact flowers, with the number of herbivores and the amount of ovary damage recorded for each flower. For each census date, I cal- 
culated the percentage of intact and aborted flowers sampled from each bush that had ovary damage. I also calculated the average number of insects in each flower.

The presence of ghost moth larvae in plants can be confirmed by the presence of sawdust-like frass coming from small exit holes (the ends of ghost moth feeding galleries) in the trunks of plants near and immediately below ground level. However, obtaining a more quantitative estimate of ghost moth abundance requires digging up plants and dissecting the upper portion of their roots. In August 1994 and September 1995 and September 1996, I randomly selected 5-8 control plants to census for ghost moth larvae. I used a shovel to expose the root of each plant at a depth $10 \mathrm{~cm}$ below ground level, severed the root, and pulled the plant out of the ground. I then dissected the root/shoot interface of each plant and counted the number of ghost moth larvae in each plant.

\section{Data analysis}

All statistical analyses were performed using SYSTAT 5.0 for Windows (SYSTAT 1992). For each of the three years, I calculated mean growth and fecundity values of lupines in each plot. I also summed fecundity and mortality values across all $3 \mathrm{yr}$ to calculate the mean cumulative fitness of plants in each experimental plot. I performed separate three-way ANOVAs on each year's data (means $\times$ plant $\times$ plot) to test the effects of block, aboveground insect suppression, belowground herbivore suppression, and the interaction of above- and belowground herbivores on mean growth, fecundity, or mortality values. Since this approach assumes independence among years, I also performed a three-way repeated-measures ANOVA on the entire data set, again with block, above-, and belowground insect suppression as main effects. Results for this analysis were qualitatively the same as the combined results from the separate ANOVAs on each year's data (both for effects of herbivore suppression on mean pod and mean total seed production), and therefore are not reported. Where necessary to normalize distributions, raw data were log transformed. While the design was originally balanced, lupine mortality caused a loss of 2 of the 28 plots ( 1 control plot and 1 aboveground insect suppression plot) after the first year. I used a one-way ANOVA (general linear model in SYSTAT) with Type III ss to analyze these unbalanced data (Shaw and Mitchell-Olds 1993) and Fisher's protected least significant difference test to compare mean fecundity values of plants in each of the three treatment plots (suppression of above-, below-, and above- + belowground herbivores) to the mean value of plants in control plots. This test was used, as all comparisons were planned; significance level was adjusted to 0.016 to account for the number of multiple comparisons (which totaled three). To calculate the effects of herbivore suppression on cumulative per plot mean plant mortality, I excluded all those plants that died from waterlogging.

\section{RESUlts}

\section{Effects of herbivores on plant fecundity}

Suppression of floral and seed herbivores had significant effects on seed pod and total seed production in two out of the three years of the study. In year one, plants on which aboveground herbivores had been suppressed produced, on average, $40 \%$ more seed pods and $31 \%$ more total seeds compared with plants exposed to these herbivores (Fig. 1, Table 1).

Protecting plants from belowground $H$. californicus herbivory had no significant effect on mean seed pod or mean total seed output (Fig. 1, Table 1), and the combined effect of above- and belowground herbivore suppression on mean seed pod and total seed production was additive (Fig. 1, Table 1). Plants protected from all herbivores produced, on average, $67 \%$ more seeds than did control plants that were exposed to ambient levels of herbivory.

The negative impacts of floral and seed consumption on lupine fecundity were even more pronounced in the second year (1995) of the study (Fig. 1). Insects destroyed many flower ovaries, and these damaged flowers were then aborted (Fig. 2). Damaged ovaries had characteristic drill holes through them, or were entirely destroyed. Often there was insect frass inside these flowers. The percentage of aborted flowers that were damaged, when summed across all census periods, was smaller on insecticide-treated plants $($ mean $=32 \%)$ compared with control plants $($ mean $=53 \%$; df $=15$, $t=-4.2 ; P<0.009)$. Across all census dates, between 2 and $15 \%$ (average $=8.4 \%$ ) of aborted flowers and $2-18 \%$ (average $=7 \%$ ) of intact flowers sampled from unsprayed plants contained ovary-damaging fly, weevil, or geometrid insect larvae. Reducing floral herbivory increased mean pod production by $82 \%$ over plants exposed to floral and seed herbivores. Plants in plots in which aboveground herbivores were suppressed produced an average of $1367 \pm 182$ pods (mean \pm SE) whereas plants in plots exposed to aboveground herbivores produced an average of $750 \pm 72$ pods. Herbivores not only damaged flowers, which induced flower abortion and reduced pod production, but they also destroyed developing seeds (Fig. 3), lowering the number of intact seeds produced per pod. As a result, the average number of seeds produced by plants protected from aboveground herbivores was significantly greater (6057 \pm 760 seeds) than those exposed to floral and seed feeding insects $(2715 \pm 800$ seeds; Fig. 1, Table $1)$. Moreover, plants in plots in which only aboveground herbivores were reduced produced significantly more seeds ( $6045 \pm 1255$ seeds $)$ than did control plants (2635 \pm 299 seeds; Fisher's PSLD multiple range test, $P=0.001)$. Suppression of belowground ghost moth larvae in year two had no significant effect on mean 

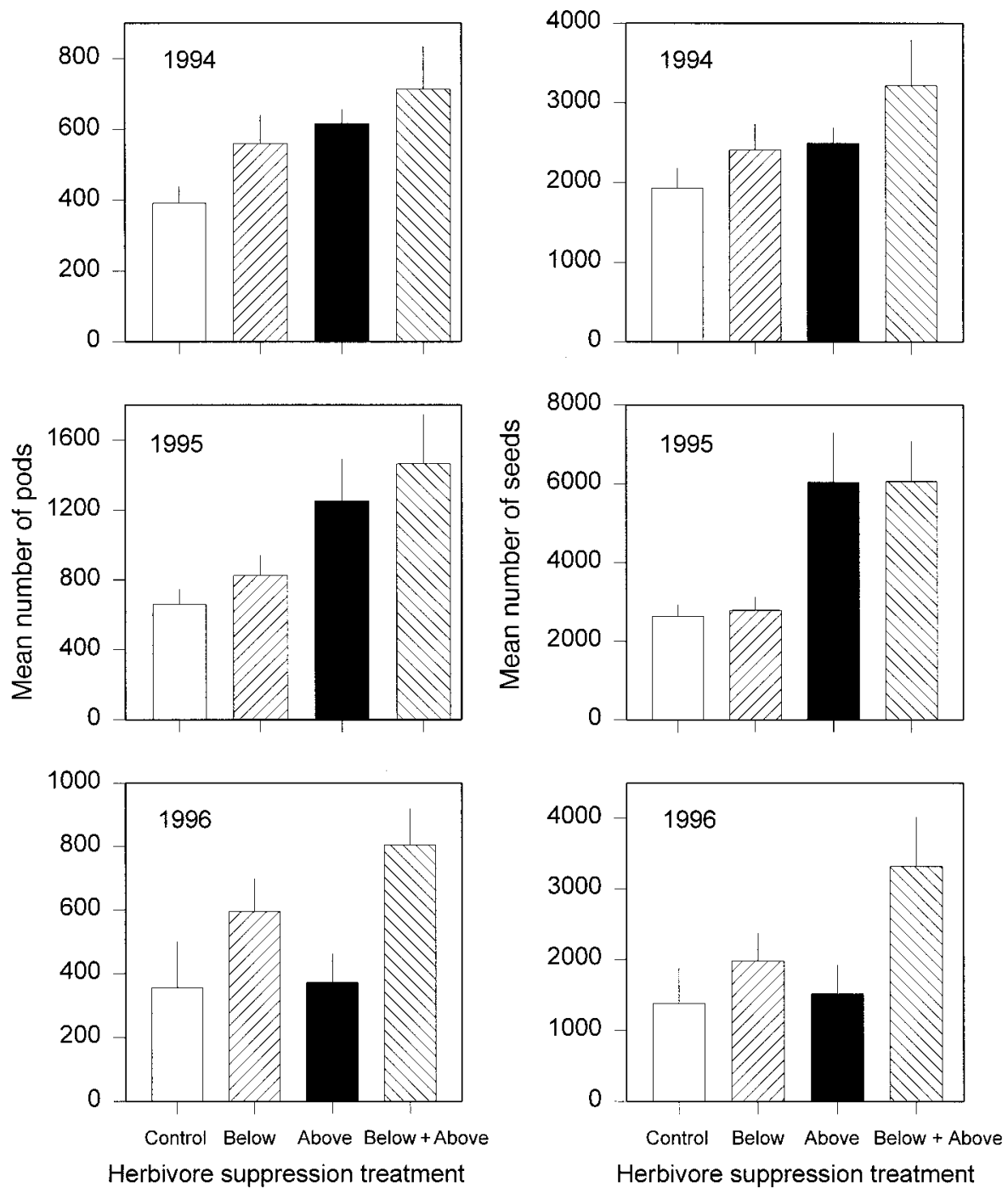

FIG. 1. Mean (+1 SE) number of seed pods (left panel) and total seeds (right panel) produced by plants within different treatment plots in each year of the experiment. Treatment plot legends: control (plants treated with water), below (plants treated with belowground insecticide), above (plants treated with foliar insecticide), and below + above (plants treated with both insecticides). ( $N=7$ plots per treatment, except in years 2 and 3 , in which $N=6$ control and aboveground plots.)

pod (per raceme or per bush) or seed production, and, as in the previous year, there was no significant interaction between above- and belowground herbivory on lupine fecundity (Table 1).

In year three (1996), a smaller percentage of aborted flowers on control plants had ovary damage (mean $=$ $35 \%$ when summed across all census periods) compared with the previous year (mean $=53 \%$ when summed across all census periods; $t$ test, $t=4.37, P$ $<0.006$; Fig. 2), and damage to developing seeds was also marginally lower in 1996 compared with 1995. Between 2 and $13 \%$ (average $=5 \%$ ) of aborted flowers and $1-20 \%$ (average $=10 \%$ ) of intact flowers from unsprayed plants contained ovary-feeding insects. As a result, although plants on which aboveground herbivores had been reduced produced more pods per ra- ceme compared with plants exposed to these herbivores, there was no significant effect of flower herbivory on mean seed pods per bush (Fig. 1, Table 1). Further, the mean number of developing seeds eaten by insects on control plants dropped from $0.50 \pm 0.06$ seeds in 1995 to $0.32 \pm 0.08$ seeds in 1996 (Fig. 3; $t$ test, $t=-1.87, P=0.098)$. Due to reduced flower and seed consumption, there was no significant effect of suppression of aboveground herbivores on mean total seed number per bush (Fig. 1, Table 1).

In contrast, plants continuously protected from ghost moth herbivory produced significantly more pods per bush compared with protected plants in year three (Table 1). Plants protected from root herbivory produced an average of $699 \pm 99$ pods and $2649 \pm 429$ seeds, an $83 \%$ increase in mean seed production compared with 
TABLE 1. Three-way ANOVA testing effect of belowground and/or aboveground insect herbivore suppression on (A) mean number of seed pods produced per raceme, (B) mean number of seed pods produced per bush, or (C) mean number of seeds produced per bush.

\begin{tabular}{|c|c|c|c|c|c|c|c|}
\hline \multirow[b]{2}{*}{ Source } & \multirow[b]{2}{*}{ df } & \multicolumn{2}{|c|}{ Year 1} & \multicolumn{2}{|c|}{ Year 2} & \multicolumn{2}{|c|}{ Year 3} \\
\hline & & MS & $F$ & MS & $F$ & MS & $F$ \\
\hline \multicolumn{8}{|c|}{ A) Seed pods per raceme } \\
\hline Block & 6 & & & 1.32 & 1.97 & 0.27 & 0.44 \\
\hline Below-ground & 1 & & & 0.84 & 1.25 & 0.94 & 1.49 \\
\hline Aboveground & 1 & & & 5.87 & $8.78 * *$ & 2.54 & $4.05 \dagger$ \\
\hline Below $\times$ above & 1 & & & 0.045 & 0.06 & 0.34 & 0.54 \\
\hline Error & 16 & & & 0.667 & & 0.63 & \\
\hline \multicolumn{8}{|c|}{ B) Seed pods per bush } \\
\hline Block & 6 & 0.25 & 1.59 & 498406 & $2.86^{*}$ & 158406 & 1.62 \\
\hline Belowground & 1 & 0.23 & 1.47 & 283939 & 1.63 & 711568 & $7.3^{*}$ \\
\hline Aboveground & 1 & 0.74 & $4.62 *$ & 2241367 & $12.88 * *$ & 93084 & 0.95 \\
\hline Below $\times$ above & 1 & 0.19 & 1.21 & 9983 & 0.057 & 48128 & 0.49 \\
\hline Error & $18 \ddagger$ & 0.16 & & 174060 & & 97886 & \\
\hline \multicolumn{8}{|c|}{ C) Total seeds per bush } \\
\hline Block & 6 & 1305561 & 1.5 & 0.34 & $2.62 \dagger$ & 2032457 & 1.18 \\
\hline Belowground & 1 & 2522400 & $3.0 \dagger$ & 0.03 & 0.226 & 10025400 & $5.8 *$ \\
\hline Aboveground & 1 & 3292800 & $3.9 \dagger$ & 3.13 & $24.17 * *$ & 4011495 & 2.34 \\
\hline Below $\times$ above & 1 & 99603 & 0.1 & 0.01 & 0.083 & 1804998 & 1.05 \\
\hline Error & $18 \ddagger$ & 837958 & & 0.13 & & 1716040 & \\
\hline
\end{tabular}

Notes: Total pod production was log transformed in year 1, and total seed production was log transformed in year 2 to normalize variance.

$\dagger P \leq 0.1 ; * P \leq 0.05 ; * * P \leq 0.01$

$\ddagger$ Error df $=16$ in years 2 and 3 .

plants exposed to subterranean herbivory, which produced an average of $379 \pm 82$ pods and an average of $1466 \pm 307$ seeds. This large effect of ghost moth herbivory on lupine fecundity occurred despite the fact that there were significantly fewer ghost moth larvae in lupine roots in year three compared with year two (mean $H$. californicus per bush $=9.0$ larvae in year two and 0.8 larvae in year three; $t$ test, $n=6 ; t=-4.1, P<$ 0.002).

In isolation, both floral and seed herbivores and ghost moth larvae significantly reduced the mean cumulative number of seed pods and seeds produced by plants over the $3 \mathrm{yr}$ of the experiment compared with plants protected from these herbivores (Fig. 4, Table 2). Suppression of both herbivores together resulted in a $94 \%$ increase in cumulative seed production compared with control plants. As in each of the three years in isolation, the combined effect of above- and belowground herbivores on cumulative female fitness was additive (Table 2).

\section{Effects of herbivores on plant growth}

Annual average growth in basal stem area of plants in different herbivore suppression plots ranged between $1309 \pm 202 \mathrm{~mm}^{2}$ and $1640 \pm 265 \mathrm{~mm}^{2}$ during 1994 (plants were 2 yr old), and ranged between $645 \pm 121$ $\mathrm{mm}^{2}$ and $941 \pm 278 \mathrm{~mm}^{2}$ during 1995 (plants were 3 yr old). Plant growth over an entire 2.5-yr span ranged from an average of $1666 \pm 298 \mathrm{~mm}^{2}$ to $2364 \pm 466$ $\mathrm{mm}^{2}$, depending on herbivore suppression treatment. Within any given year or across the entire length of the experiment, there was no statistically significant effect of above- or belowground herbivory on lupine growth (Table 3).

\section{Effects of herbivores on plant mortality}

Ghost moth herbivory killed many plants in the early fall of each year. Plants died after they had set seed, but often before large ghost moth larvae inside plant shoots and roots had pupated. Plants continuously exposed to these herbivores had significantly greater mortality than plants protected from them (Fig. 5, Table 4). There were, on average, $2.5 \pm 1.5,9 \pm 1.9$, and $0.8 \pm 0.5$ caterpillars in lupines exposed to ghost moth herbivory in years one, two, and three of the experiment, respectively.

\section{Discussion}

Generalizing about the selective effects of insect herbivores on plants has proven difficult. On the one hand, the enormous plant-herbivore literature is rife with studies documenting negative effects of herbivory on plant performance (reviews by Belsky 1986, Crawley 1989, Marquis 1992). Yet on the other hand, replicated experimental studies examining demographic impacts of ambient levels of herbivory on native plants in natural populations are still scarce (but see Louda 1982b, Louda and Potvin 1995).

In this study, both in isolation and in tandem, belowand aboveground herbivores had sizable effects on lupine fitness. Suppression of floral and seed herbivores increased mean cumulative seed production over $3 \mathrm{yr}$ by $45 \%$. Suppression of root boring ghost moth larvae increased mean cumulative seed production by $28 \%$, 

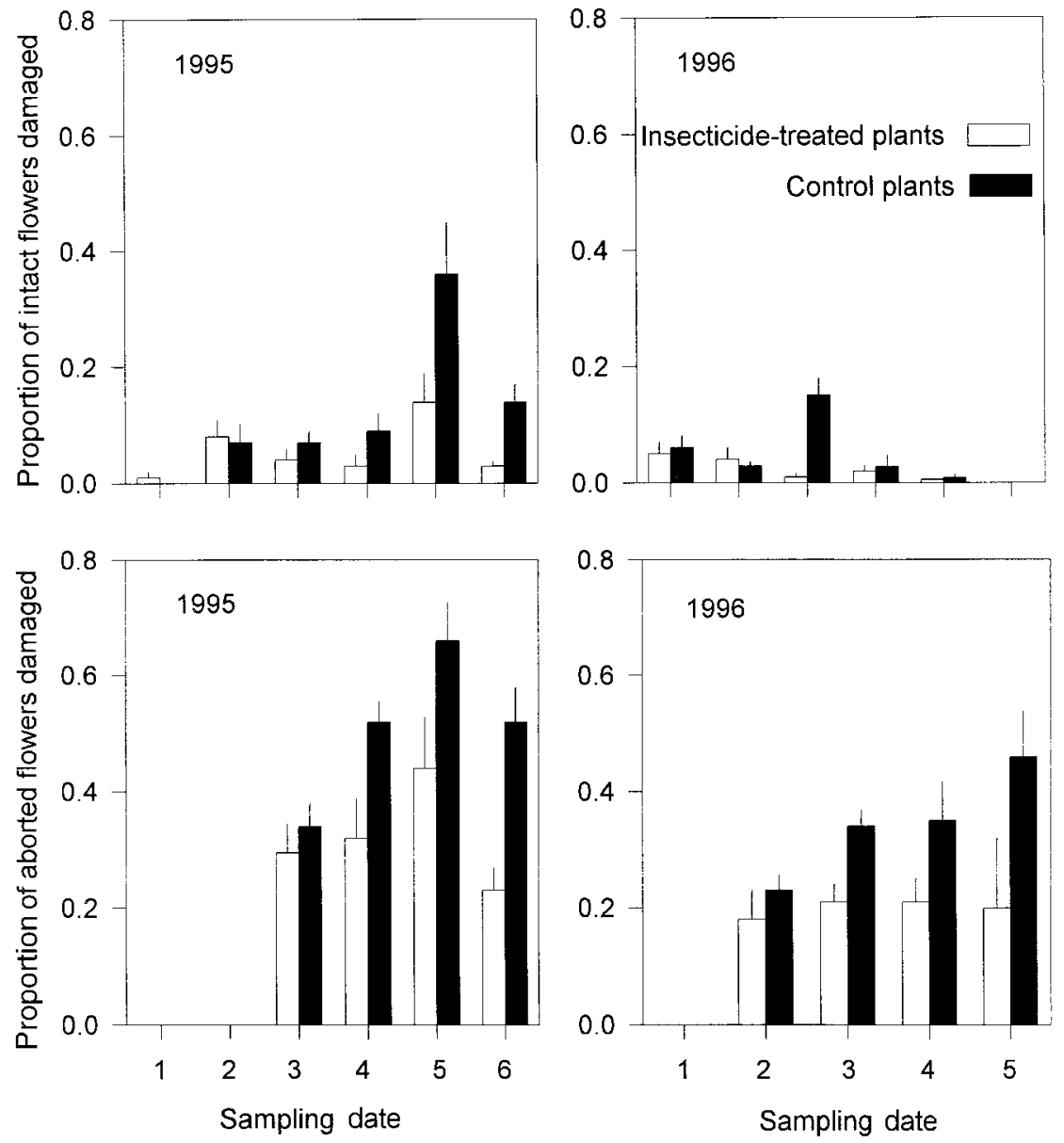

FIG. 2. Mean (+1 SE) fraction of intact (top panel) and aborted (bottom panel) flowers with insect-damaged ovaries in parallel experiment in 1995 (year two of insect exclusion experiment) and in 1996 (year three of insect exclusion experiment). Sampling dates were approximately every 2 wk from 25 April (sampling date 1 in 1995) or 6 May (sampling date 1 in 1996) to 3 July (sampling date 6 in 1995 and sampling date 5 in 1996). Open bars represent plants treated with foliar insecticide; solid bars represent control plants ( $N=8$ individuals).

and increased survival by $18 \%$. Suppression of both above- and belowground herbivores together resulted in a $94 \%$ increase in mean cumulative fecundity compared with plants exposed to ambient levels of herbivory. Insect herbivores therefore have great potential to act as potent agents of selection on bush lupine.

Aboveground herbivores were small, inconspicuous, and could not be seen by superficially examining flower or seed pods on plants. Estimating the magnitude of herbivore damage to flowers by censusing only intact flowers on plants proved deceptive, since damaged flowers were aborted, leaving mostly undamaged flowers on plants. In year two, when suppression of aboveground herbivores had the largest effect on lupine fecundity, damage to aborted flowers was high, and the percentage of aborted flowers that were damaged increased through the flowering season, as insect larvae matured. Although undamaged flowers were also aborted, there was less damage, less abortion, and, conse- quently, greater fruit production on plants treated with insecticide compared with control plants.

Flower- and seed-feeding insects are evanescent, as is their damage to plants (Louda 1989, Louda and Potvin 1995). I found substantial differences among years in the effects of floral- and seed-feeding insects on lupine fitness. Yet despite the fact that there was an extremely strong effect of aboveground herbivory on lupine fecundity in only one year in three, the cumulative impact of annual losses in seed production was very large. Plants were unable to fully compensate across years for continual reductions in seed output. Although I lack an estimate of how herbivory alters lifetime female reproductive success, this study covered more than a third of the 7-10 yr life-span of a typical lupine (Davidson 1975, Strong et al. 1995). Further, it may be that the majority of lupine seed production occurs when plants are young.

My estimate of the effect of aboveground herbivory 


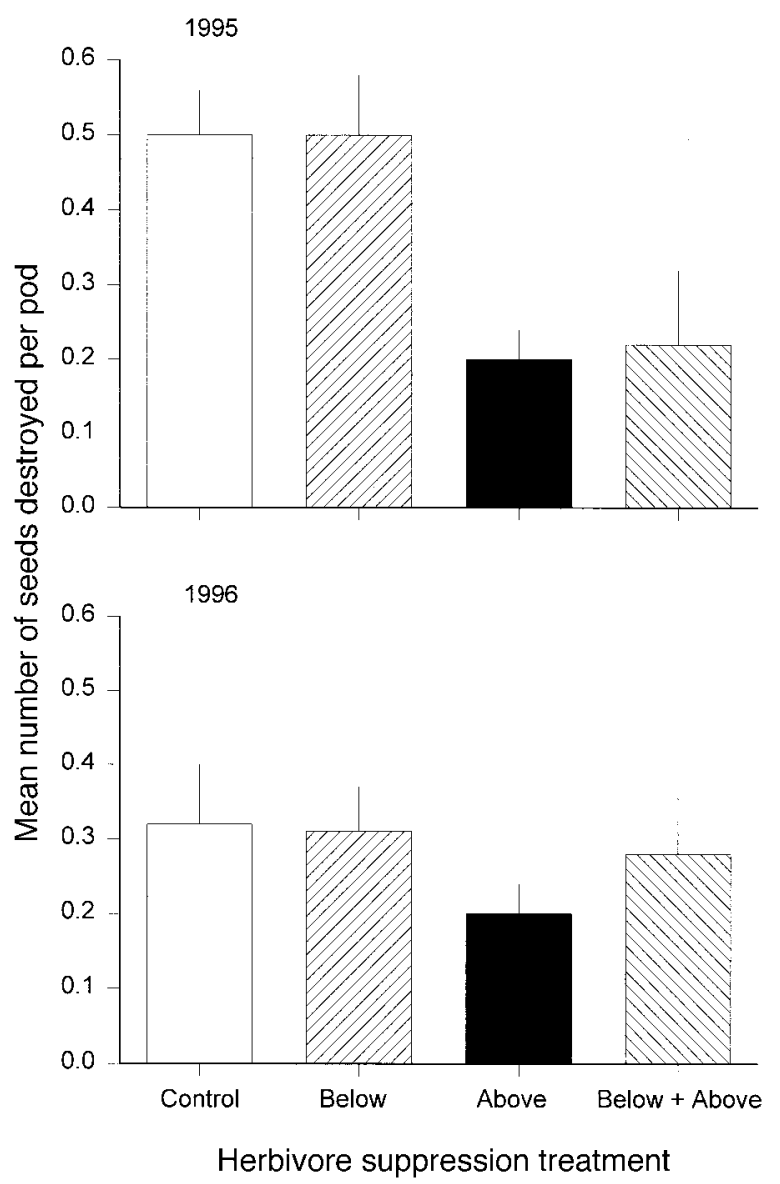

FIG. 3. Mean (+1 SE) number of insect-destroyed seeds per pod on plants in different treatment plots in 1995 (year two) and 1996 (year three of the experiment). Treatment plot legends are as in Fig. 1. $(N=7$ plots per treatment, except in years 2 and 3 in which $N=6$ control and above plots.)

on lupine fecundity is conservative for the following reasons. First, insecticide application never entirely eliminated insects or insect damage to flowers and seeds. Second, in year one of the experiment, I was misled by the superficial lack of insect damage to plants and prematurely stopped insecticide application at the end of May, rather than continuing to treat plants through June, as I did in years two and three. As a
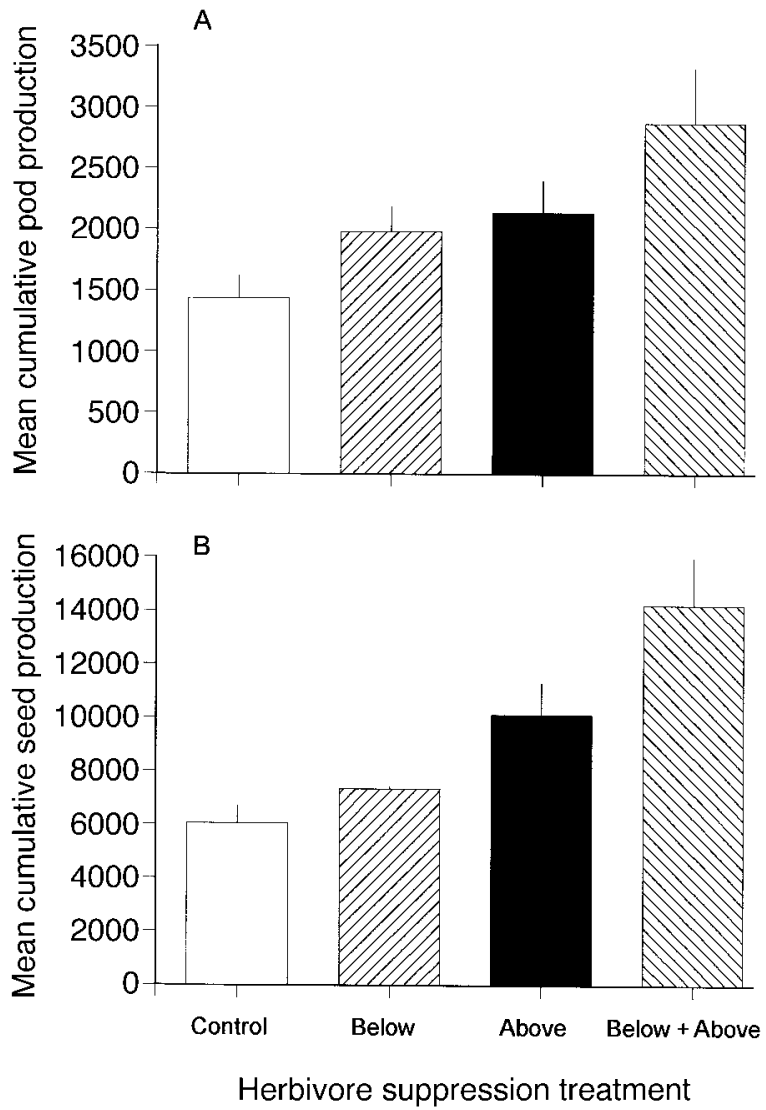

FIG. 4. Cumulative (+1 SE) mean seed pod (A) or seed (B) production per plant in different treatment plots. Mean pod and seed production are summed across all three years of the study. Treatment plot legends are as in Fig. $1 .(N=6$ plots per treatment.)

result, I may have underestimated the effect of aboveground herbivores on plants in year one. Finally, during the course of the experiment, a few individuals across all treatment plots were attacked by leaf (Dasineura lupinorum), stem (Neolasioptera lupini) and bud (Dasineura lupini) galling midges (Diptera, Cecidomyiidae). Insecticide treatment had little effect on these internally feeding herbivores. Thus, the combined influence of all invertebrate herbivores on lupine fitness is undoubtedly greater than that found in this study.

TABLE 2. Three-way ANOVA testing effect of belowground and/or aboveground insect herbivore suppression on cumulative mean number of seed pods and mean total number of seeds produced per bush across all three years in which reproduction was monitored. Total seed production was $\log$ transformed to normalize variance.

\begin{tabular}{|c|c|c|c|c|c|}
\hline \multirow[b]{2}{*}{ Source } & \multicolumn{3}{|c|}{ Pod } & \multicolumn{2}{|c|}{ Seed } \\
\hline & $\mathrm{df}$ & MS & $F$ & MS & $F$ \\
\hline Block & 6 & 968371 & 2.17 & 0.22 & $2.91 *$ \\
\hline Belowground & 1 & 1727646 & $3.88 \dagger$ & 0.45 & $5.92 *$ \\
\hline Aboveground & 1 & 3299670 & $7.41 *$ & 1.72 & $22.7 * *$ \\
\hline Below $\times$ above & 1 & 9377 & 0.02 & 0.01 & 0.13 \\
\hline Error & 16 & 445468 & & 0.08 & \\
\hline
\end{tabular}

\footnotetext{
$\dagger P \leq 0.10 ; * P \leq 0.05 ; * * P<0.01$
} 
TABLE 3. Three-way ANOVA testing effect of block, belowground and/or aboveground insect herbivore suppression on mean lupine stem growth (measured as changes in stem basal area) over $1 \mathrm{yr}, 2 \mathrm{yr}$, and $2.5 \mathrm{yr}$.

\begin{tabular}{|c|c|c|c|c|c|c|c|}
\hline \multirow[b]{2}{*}{ Source } & \multirow[b]{2}{*}{$\mathrm{df}$} & \multicolumn{2}{|c|}{$1 \mathrm{yr}$} & \multicolumn{2}{|c|}{$2 \mathrm{yr}$} & \multicolumn{2}{|c|}{$2.5 \mathrm{yr}$} \\
\hline & & MS & $F$ & MS & $F$ & MS & $F$ \\
\hline Block & 6 & 197565 & 0.68 & 685158 & 0.96 & 1071601 & 1.01 \\
\hline Belowground & 1 & 730 & 0.003 & 193492 & 0.27 & 3177268 & 3.0 \\
\hline Aboveground & 1 & 379324 & 1.3 & 1292897 & 1.8 & 2697 & 0.003 \\
\hline Below $\times$ above & 1 & 68310 & 0.24 & 4831 & 0.007 & 426996 & 0.4 \\
\hline Error & $18 \dagger$ & 290465 & & 714318 & & 1058082 & \\
\hline
\end{tabular}

$\dagger$ Error df $=16$ in years 2 and 3 .

Belowground herbivory by ghost moth larvae altered both fecundity and survival components of plant fitness. Ghost moths significantly reduced lupine fecundity, but only in year three (Table 1). This delayed impact of subterranean herbivory on plant fecundity suggests a cumulative effect of chronic exposure to root boring rather than any sudden increase in herbivory during year three. My interpretation is supported by the fact that ghost moth larvae occurred at low density in year three compared with previous years. Even when at high density in year two (1995), ghost moth larvae had no significant effect on lupine fecundity during the year of heavy root damage. Thus, it seems unlikely that the low numbers of caterpillars in year three alone could have depressed lupine fecundity. Rather, a cumulative impact is more likely, since plant roots became progressively more damaged throughout the experiment. After the summer of year two, when ghost moth larvae were very abundant, plants exposed to ghost moth herbivory had stems that were split and roots that were extensively engraved and bored; root

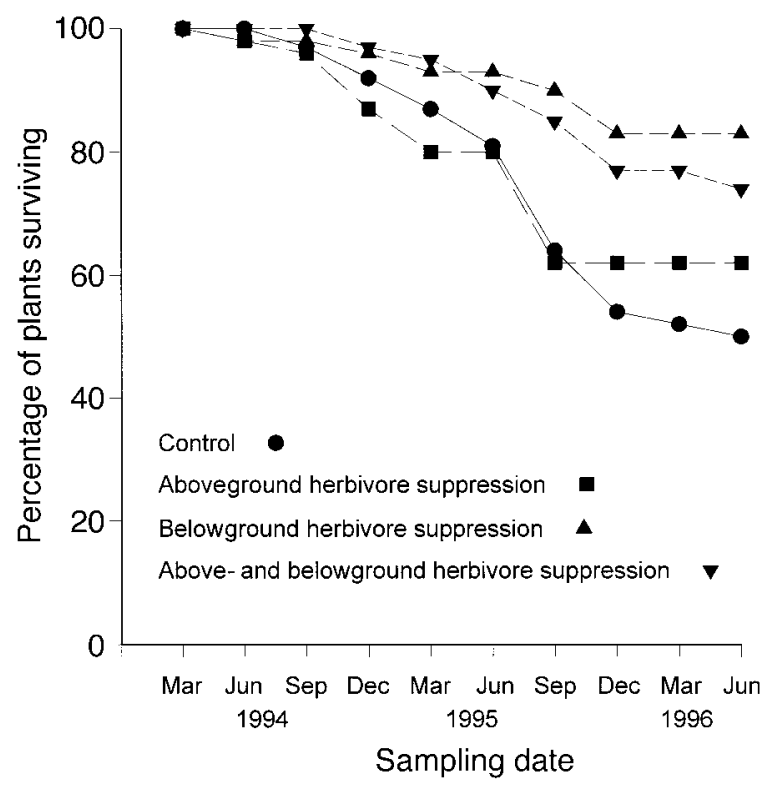

FIG. 5. Mean percentage of plants surviving throughout the study in different treatment plots $(N=6-7$ plots, depending on year; see Methods section for details). and trunk damage was noticeably less severe after only $1 \mathrm{yr}$ of exposure to $H$. californicus. These observations bolster the general suggestion that the effects of insect herbivory on perennial plant fecundity may not be manifested immediately, which cautions against short-term herbivory studies on perennial plants (Gange 1990). Although belowground insect herbivores have been shown to affect the fecundity of herbaceous plants in natural systems (Prins et al. 1992), this is one of the first examples of a belowground insect herbivore depressing both annual and cumulative fecundity of a woody perennial.

Many plants are attacked by multiple species of insect herbivores. Interactions among these different species can affect the subsequent densities of the interacting species (Niemela et al. 1984, Williams and Myers 1984, Faeth 1986, Moran and Whitham 1990, Pilson 1996), but it is often unknown how this, in turn, affects the relative selection pressures imposed on plants by each of the species involved (Hougen-Eitzman and Rausher 1994). Experiments that compare the independent and combined effects of different species of insect herbivores on plant fitness are rare (HougenEitzman and Rausher 1994, Wise and Sacchi 1996), and few studies have explicitly examined how aboveand belowground herbivory differ or interact with each other to affect plant fitness (but see Muller-Scharer and Brown 1995). Results from this study show that the effects of above- and belowground herbivory on plant fitness were additive in all years.

The most dramatic manifestation of ghost moth herbivory on plant fitness was the death of plants. This corroborates previous research that implicated ghost moth herbivory in large die-offs of lupine at BMR and

TABLE 4. Three-way ANOVA testing effect of belowground and/or aboveground insect herbivore suppression on cumulative mean plant mortality over 3.0 yr.

\begin{tabular}{lcll}
\hline \hline \multicolumn{1}{c}{ Source } & df & \multicolumn{1}{c}{ MS } & $F$ \\
\hline Block & 6 & 0.035 & 0.72 \\
Belowground & 1 & 0.21 & $4.4^{*}$ \\
Aboveground & 1 & 0.001 & 0.02 \\
Below $\times$ above & 1 & 0.05 & 1.07 \\
Error & 18 & 0.05 & \\
\hline
\end{tabular}

$* P \leq 0.05$ 
several nearby sites (Strong et al. 1995). Estimates of lupine mortality due to ghost moth herbivory are likely underestimates, because mortality from herbivory was assumed to be the difference in survival between plants in Hepialus suppression and the plants in the control plots. However, in plots in which both above- and belowground herbivores were excluded, some plants died from shading, not from herbivory. These shaded plants were often small and upon dissection showed no evidence of ghost moth infestation. This may explain why survivorship curves of plants protected from all herbivores and plants protected from just belowground herbivores diverge (although the end points are not statistically distinct).

High plant mortality due to heavy insect herbivory is not considered the norm in native plant communities (Crawley 1989). Yet the effects of belowground herbivores on plant demography are just beginning to be understood. Given the number and diversity of subterranean invertebrate herbivores, we have probably underestimated the importance of a major component of plant herbivory. Belowground herbivory is certainly damaging to plants; experimental studies show that shrub (Parker 1985) and forb (Brown 1990, Brown and Gange 1992) cover increase when plants are protected from belowground insects. Seedling recruitment can also be enhanced by protection from subterranean in sect herbivory (Gange et al. 1991; D. R. Strong et al., unpublished manuscript). Species, such as lupines, with single, long taproots may be particularly vulnerable to root borers.

In spite of the fact that lupine plants and seeds suffer high mortality (this study, Strong et al. 1995, Maron 1997, Maron and Simms 1997), lupines remain abundant in the coastal prairie grasslands on BMR. The key to this resilience is the ability of these plants to grow fast and set viable seed before they die from belowground herbivory. Between their first and second year, control lupines added, on average, $4 \mathrm{~cm}$ to their stem diameter. Canopy diameter can expand by $>1 \mathrm{~m}$. In their first year of reproduction, even plants exposed to insect herbivory can produce over 2000 seeds. Many of these seeds remain dormant in a long-lived seed bank (Maron and Simms 1997), and in fact, during this study there was no seedling recruitment into experimental plots. Thus, although insect herbivory alters lupine abundance, and occasionally kills entire stands, it does so without creating a "brown world" (sensu Hairston et al. 1960). Rather than limiting plants to a subset of available habitat, or making plants rare, insect herbivory simply reduces the density of an abundant shrub. In fact, since lupine seedlings do not recruit under adult plants, adult mortality may actually facilitate seedling establishment. This suggests that the longstanding debate over whether insect herbivores influence plant population dynamics might be fruitfully shifted away from simply asking whether insects alter plant abun- dance, and instead focus on the more subtle details of how plant population dynamics respond to herbivory.

\section{ACKNOWLEDGMENTS}

I thank Michelle Bondonno, Ana Child, Cheryl Dean, David Ginsburg, Sean McNeil, and Venessa Rashbrook for their great help in the field. Thanks to F. Christian Thompson at the Systematic Entomology Laboratory, Agricultural Research Service, U.S. Department of Agriculture for identifying the unknown Dipteran seed predator. Anurag Agrawal, Susan Harrison, Rick Karban, Kevin Rice, Sharon Strauss, and Donald Strong all read and improved versions of this paper. Financial support was provided by the Bodega Field Conference, the California Native Plant Society, The U.C. Bodega Marine Laboratory, The U.C. Natural Reserve System's Mildred Mathias Fund, and the U.C. Davis Center for Population Biology and Ecology Graduate Group. I am extremely grateful to all of these sources of financial support.

\section{LiterATURE Cited}

Andersen, A. N. 1988. Insect seed predators may cause far greater losses than they appear to. Oikos 52:337-340.

. 1989. Pre-dispersal seed losses to insects in species of Leptospermum (Myrtaceae). Australian Journal of Ecology 14:13-18.

Andersen, D. C. 1987. Below-ground herbivory in natural communities: a review emphasizing fossorial animals. Quarterly Review of Biology 62:261-286.

Auld, T. D. 1986. Variation in predispersal seed predation in several Australian Acacia spp. Oikos 47:319-326.

Auld, T. D., and P. J. Myerscough. 1986. Population dynamics of the shrub Acacia suaveolens (Sm.) Willd.: seed production and predispersal seed predation. Australian Journal of Ecology 11:219-234.

Barbour, M. G., R. B. Craig, R. R. Drysdale, and M. T. Ghiselin. 1973. Coastal ecology of Bodega Head. University of California Press, Berkeley, California, USA.

Belsky, A. J. 1986. Does herbivory benefit plants? A review of the evidence. American Naturalist 127:870-892.

Bentley, B. L., and N. D. Johnson. 1994. The impact of defoliation by a tussock moth, Orgyia vetusta, on a nitrogen-fixing legume, Lupinus arboreus. Pages 169-178 in J. L. Sprent, and D. McKey, editors. Advances in legume systematics, Part 5. The nitrogen factor. Royal Botanic Gardens, Kew, UK.

Brown, V. K. 1990. Insect herbivory and its effect on plant succession. Pages 275-288 in J. J. Burdon, and S. R. Leather, editors. Pests, pathogens and plant communities. Blackwell Scientific, Oxford, UK.

Brown, V. K., and A. C. Gange. 1989a. Differential effects of above-and below-ground insect herbivory during early plant succession. Oikos 54:67-76.

Brown, V. K., and A. C. Gange. 1989b. Herbivory by soildwelling insects depresses plant species richness. Functional Ecology 3:667-671.

Brown, V. K., and A. C. Gange. 1990. Insect herbivory below ground. Advances in Ecological Research 20:1-58.

Brown, V. K., and A. C. Gange. 1992. Secondary plant succession-how is it modified by insect herbivory. Vegetatio 101:3-13.

Clements, R. O., and B. R. Bentley. 1983. The effect of three pesticide treatments on the establishment of white clover (Trifolium repens) sown with a slot seeder. Crop Protection 2:375-378.

Clements, R. O., B. R. Bentley, and C. A. Jackson. 1986. The impact of granular formulations of phorate, terbufos, carbofuran, carbosulphan, and thiofanox on newly sown Italian ryegrass (Lolium multiflorum). Crop Protection 5: 389-394.

Clements, R. P., R. Asteraki, and C. A. Jackson. 1988. A 
method to study the effects of chlorpyrifos on predatory ground beetles in grassland. Pages 167-174 in M. P. Greaves, B. D. Smith, and P. W. Greig-Smith, editors. Field methods for the study of environmental effects of pesticides. Proceedings of the Symposium of the British Crop Protection Council, Monograph 40. BCPC Publications, Thornton Heath, UK.

Crawley, M. J. 1989. Insect herbivores and plant population dynamics. Annual Review of Entomology 34:531-564.

Davidson, E. D. 1975. Demography of Lupinus arboreus at Bodega Head, California. Dissertation. University of California, Davis, California, USA.

Detling, J. K., D. T. Winn, C. Procter-Gregg, and E. L. Painter. 1980. Effects of simulated grazing by below-ground herbivores on growth, $\mathrm{CO}_{2}$ exchange, and carbon allocation patterns of Bouteloua gracilis. Journal of Applied Ecology 17:771-778.

Doak, D. F. 1992. Lifetime impacts of herbivory for a perennial plant. Ecology 73:2086-2009.

Dowler, W. M., and S. D. Van Gundy. 1984. Importance of agricultural plant nematology. Pages 1-12 in W. R. Nicklel, editor. Plant and insect nematodes. Marcel Dekker, New York, New York, USA

Dutcher, J. D., and J. N. All. 1979. Damage impact of larval feeding by the grape root borer in a commercial concord grape vineyard. Journal of Economic Entomology 72:159161

Faeth, S. H. 1986. Indirect interactions between temporally separated herbivores mediated by the host plant. Ecology 67:479-494.

Fox, L. R. 1981. Defense and dynamics in plant-herbivore systems. American Zoologist 21:853-864.

Gadgil, R. L. 1971. The nutritional role of Lupinus arboreus in coastal sand dune forestry. 3. Nitrogen distribution in the ecosystem before tree planting. Plant and Soil 35:113126

Gange, A. C. 1990. Effects of insect herbivory on herbaceous plants. Pages 49-62 in J. J. Burdon, and S. R. Leather, editors. Pests, pathogen and plant communities. Blackwel Scientific, Oxford, UK

Gange, A. C., and V. K. Brown. 1989. Effects of root herbivory by an insect on a foliar-feeding species, mediated through changes in the host plant. Oecologia 81:38-42.

Gange, A. C., V. K. Brown, and L. M. Farmer. 1991. Mechanisms of seedling mortality by subterranean insect herbivores. Oecologia 88:228-232.

Godfrey, L. D., D. E. Legg, and K. V. Yeargan. 1986. Effects of soil-borne organisms on spring alfalfa establishment in an alfalfa rotation system. Journal of Economic Entomology 79:1055-1063.

Hagner, M., and C. Jonsson. 1995. Survival after planting without soil preparation for pine and spruce seedlings protected from Hylobious abietis by physical and chemical shelters. Scandinavian Journal of Forest Research 10:225234.

Hairston, N. G., F. E. Smith, and L. B. Slobodkin. 1960 Community structure, population control, and competition. American Naturalist 94:421-425.

Harrison, S. 1994. Resources and dispersal as factors limiting a population of the tussock moth (Orgyia vetusta), a flightless defoliator. Oecologia 99:27-34.

Harrison, S., and R. Karban. 1986. Effects of an early-season folivorous moth on the success of a later-season species, mediated by a change in the quality of the shared host, Lupinus arboreus Sims. Oecologia 69:354-359

Harrison, S., and J. L. Maron. 1995. Impacts of defoliation by tussock moths (Orgyia vetusta) on the growth and reproduction of bush lupine (Lupinus arboreus). Ecological Entomology 20:223-229.

Hendrix, S. D. 1988. Herbivory and its impact on plant re- production. Pages 246-263 in J. Lovett Doust, and L. Lovett Doust, editors. Plant reproductive ecology. Oxford University Press, Oxford, UK.

Hougen-Eitzman, D., and M. D. Rausher. 1994. Interactions between herbivorous insects and plant-insect coevolution. American Naturalist 143:677-697.

Houle, G., and G. Simard. 1996. Additive effects of genotype, nutrient availability and type of tissue damage on the compensatory response of Salix planifolia spp. planifolia to simulated herbivory. Oecologia 107:373-378.

Ingham, R. E., and J. K. Detling. 1986. Effects of defoliation and nematode consumption on growth and leaf gas exchange in Bouteloua curtipendula. Oikos 46:23-28.

Kuhr, R. J., and H. W. Dorough. 1976. Carbamate insecticides: chemistry, biochemistry, and toxicology. CRC Press, Cleveland, Ohio, USA.

Louda, S. M. 1982a. Limitation of the recruitment of the shrub Haplopappus squarrosus (Asteraceae) by flower- and seed-feeding insects. Journal of Ecology 70:43-53.

- 1982b. Distribution ecology: variation in plant recruitment over a gradient in relation to insect seed predation. Ecological Monographs 52:25-41.

1983. Seed predation and seedling mortality in the recruitment of a shrub, Haplopappus venetus (Asteraceae), along a climatic gradient. Ecology 64:511-521.

- 1989. Predation in the dynamics of seed regeneration. Pages 25-51 in M. A. Leck, V. T. Parker, and R. L. Simpson, editors. Ecology of Soil Seed Banks. Academic Press, New York, New York, USA.

Louda, S. M., and M. A. Potvin. 1995. Effect of inflorescence-feeding insects on the demography and lifetime fitness of a native plant. Ecology 76:229-245.

Maron, J. L. 1996. Herbivory on bush lupine (Lupinus arboreus): effects on plant demography and implications for community and ecosystem-level processes. Dissertation. University of California, Davis, California, USA.

- 1997. Interspecific competition and insect herbivory reduce bush lupine (Lupinus arboreus) seedling survival. Oecologia 110:284-290.

Maron, J. L., and P. G. Connors. 1996. A native nitrogenfixing shrub facilitates weed invasion. Oecologia 105:302312.

Maron, J. L., and E. L. Simms. 1997. Effect of seed predation on seed bank size and seedling recruitment of bush lupine (Lupinus arboreus). Oecologia 111:76-84.

Marquis, R. J. 1992. The selective impact of herbivores. Pages 301-325 in R. S. Fritz, and E. L. Simms, editors. Plant resistance to herbivores and pathogens. University of Chicago Press, Chicago, Illinois, USA.

Martin, M. A., N. Cappuccino, and D. Ducharme. 1994. Performance of Symydobius americanus (Homoptera: Aphididae) on paper birch grazed by caterpillars. Ecological Entomology 19:6-10.

Masters, G. J. 1995. The impact of root herbivory on aphid performance: field and laboratory evidence. Acta Oecologia 16:135-142.

Masters, G. J., V. K. Brown, and A. C. Gange. 1993. Plant mediated interactions between above- and below-ground insect herbivores. Oikos 66:148-151.

Mattson, W. J., P. Niemela, and M. Rousi, editors. 1996. Dynamics of forest herbivory: quest for pattern and principle. Page 286, United States Department of Agriculture, General Technical Report NC-183, St. Paul, Minnesota, USA.

Moran, N. A., and T. G. Whitham. 1990. Differential colonization of resistant and susceptible host plants: Pemphigus and Populus. Ecology 71:1059-1067.

Muller-Scharer, H. 1991. The impact of root herbivory as a function of plant density and competition-survival, 
growth and fecundity of Centaurea maculosa in field plots. Journal of Applied Ecology 28:750-776.

Muller-Scharer, H., and V. K. Brown. 1995. Direct and indirect effects of above- and below- ground insect herbivory on plant density and performance of Tripleurospermum per foratum during early plant succession. Oikos 72:36-41.

Niemela, P., J. Tuomi, R. Mannila, and P. Ohala. 1984. The effect of previous damage on the quality of Scots pine foliage as food for diprionid sawflies. Zeitschrift fur angewandte Entomologie 98:33-43.

Opler, P. A. 1968. Unusual numbers of Hepialus sequoiolus Behrens in Sonoma County. Pan-Pacific Entomologist 36: 45.

Parker, M. A. 1985. Size-dependent herbivore attack and the demography of an arid grassland shrub. Ecology 66:850860.

Pilson, D. 1996. Two herbivores and constraints on selection for resistance in Brassica rapa. Evolution 50:1492-1500.

Pozo, C., M. V. Martinez-Toledo, V. Salmeron, B. Rodelas, and J. Gonzalez-Lopez. 1995. Effect of chlorpyrifos on soil microbial activity. Environmental Toxicology and Chemistry 14:187-192.

Prins, A. H., H. W. Nell, and P. G. L. Klinkhamer. 1992 Size-dependent root herbivory on Cynoglossum officinale. Oikos 65:409-413.

Reichman, O. J., and S. C. Smith. 1991. Responses to simulated leaf and root herbivory by a biennial, Tragopogon dubius. Ecology 72:116-124.

Revellin, C., B. de Canson, and G. Catroux. 1992. Effect of a mixture of cholorpyrifos and Lindane on the symbiosis of Bradyrhizobium japonicum and Soybean (Glycine max. (L.) Merril). Pesticide Science 36:69-74.

Root, R. B. 1996. Herbivore pressure on goldenrods (Solidago altissima) - its variation and cumulative effects. Ecology 77:1074-1087.

Scott, J. A., N. R. French, and J. W. Leetham. 1979. Patterns in consumption in grasslands. Pages 89-105 in N. R. French, editor. Perspectives in grassland ecology. Springer, New York, New York, USA.

Seastedt, T. R., R. A. Ramundo, and D. C. Hayes. 1988. Maximization of densities of soil animals by foliage herbivory: empirical evidence, graphical and conceptual models. Oikos 51:243-248.

Shaw, R. G., and T. Mitchell-Olds. 1993. ANOVA for unbalanced data: an overview. Ecology 74:1638-1645.

Strauss, S. Y. 1991. Direct, indirect, and cumulative effects of three native herbivores on a shared host plant. Ecology 72:543-558.

Strong, D. R., J. L. Maron, P. G. Connors, A. V. Whipple, S. Harrison, and R. L. Jefferies. 1995. High mortality, fluctuation in numbers, and heavy subterranean insect herbivory in bush lupine, Lupinus arboreus. Oecologia 104:8592.

SYSTAT. 1992. SYSTAT for Windows: statistics, version 5 edition. Systat, Evanston, Illinois, USA.

Wagner, D. L. 1986. The biosystematics of Hepialis F.s. lato, with special emphasis on the californicus-hectoides species group. Dissertation. University of California, Berkeley, California, USA

Waloff, N., and O. W. Richards. 1977. The effect of insect fauna on growth mortality and natality of broom, Sarothamnus scoparius. Journal of Applied Ecology 14:787798.

Williams, K. S., and J. H. Myers. 1984. Previous herbivore attack of red alder may improve food quality for fall webworm larvae. Oecologia 63:166-170.

Wise, M. J., and C. F. Sacchi. 1996. Impact of two specialist insect herbivores on reproduction of horse nettle, Solanum carolinense. Oecologia 108:328-337.

Zammit, C., and C. W. Hood. 1986. Impact of flower and seed predators on seed-set in two Banksia shrubs. Australian Journal of Ecology 11:187-193. 